САУРОВА Т. А.

\title{
ИССЛЕДОВАНИЕ ХАРАКТЕРИСТИК АВТОФАЗНОЙ МНОГОЛУЧЕВОЙ ЛАМПЫ БЕГУЩЕЙ ВОЛНЫ С ПЕРЕМЕННОЙ ФАЗОВОЙ СКОРОСТЬЮ
}

\author{
Национальный технический университет Украиньь \\ «Киевский политехнический институт», \\ Украина, Киев, 03056, пр-т Победь 37
}

\begin{abstract}
Аннотация. Проведено численное исследование основных характеристик автофазной многолучевой лампы бегущей волны (АМЛБВ) с переменной фазовой скоростью, группирующий участок замедляющей системы которой содержит одну секцию с пониженным значением сопротивления связи. Выполнена экспериментальная верификация численной нелинейной модели АМЛБВ, подтверждающая адекватность описания взаимодействия электронного потока с электромагнитной волной в таком приборе
\end{abstract}

Ключевые слова: ЛБВ; лампа бегущей волны; автофазный режим; автофазная лампа бегущей волны; способ усиления СВЧ сигнала

\section{ВВЕДЕНИЕ}

Применение в лампе бегущей волны (ЛБВ) электронного потока, состоящего из нескольких пучков, каждый из которых движется в отдельном пролетном канале, позволяет существенно снизить рабочие напряжения и увеличить первеанс потока [1]. Коэффициент полезного действия (КПД) многолучевой ЛБВ (МЛБВ) возможно повысить при помощи режима захвата электронных сгустков (автофазного режима) во всех лучах полем электромагнитной волны замедляющей системы (ЗС).

В [2] предложены способ выполнения и схема конструкции автофазной многолучевой ЛБВ (АМЛБВ), позволяющие получить высокий КПД. В [3] разработана численная нелинейная одномерная модель АМЛБВ с переменной фазовой скоростью, на основе которой проведены расчеты для широкого спектра параметров таких приборов и их анализ.
Данная работа посвящена исследованию основных характеристик АМЛБВ с переменной фазовой скоростью и экспериментальной верификации ее численной нелинейной одномерной модели.

\section{ИСХОДНЫЕ ПОЛОЖЕНИЯ}

Уравнения численной нелинейной модели АМЛБВ, полученные на основе одномерных нелинейных уравнений классической МЛБВ [1] с учетом наличия участка ЗС с уменьшенным сопротивлением связи, для идентичных лучей имеют следующий вид:

$$
\begin{gathered}
\frac{\partial Z}{\partial x}=W, \\
\frac{\partial W}{\partial x}=-(1+C W)^{3} \times \\
\times\left\{\operatorname{Re} \sum_{k} \mathrm{j} \frac{q_{k}}{k} I_{k} \exp (\mathrm{j} k Z)+a \operatorname{Re} \dot{F} \exp (\mathrm{j} Z)\right\},
\end{gathered}
$$

